\title{
EVALUASI KANDUNGAN NUTRIEN KONSENTRAT SAPI PERAH RAKYAT DI KABUPATEN MALANG
}

\author{
Nutrient Content Evaluation of Concentrate for Dairy Cattle in Malang \\ Regency \\ Rizka Muizzu Aprilia ${ }^{1)}$, Hartutik $^{2)}$, dan Marjuki ${ }^{2)}$ \\ ${ }^{1)}$ Mahasiswa Fakultas Peternakan, Universitas Brawijaya, Malang-65145, Indonesia \\ ${ }^{2)}$ Dosen Minat Nutrisi dan Makanan Ternak, Fakultas Peternakan, Universitas Brawijaya, Malang-65145, \\ Indonesia \\ Email :marjuki@ub.ac.id
}

\begin{abstract}
ABSTRAK
Tujuan dari penelitian ini adalah untuk mengetahui nilai kandungan nutrien pakan konsentrat yang diberikan peternak rakyat pada sapi perah rakyat di Kecamatan Gondanglegi, Jabung dan Pujon. Materi yang digunakan dalam penelitian ini adalah seluruh bahan pakan konsentrat yang diberikan peternak rakyat di ketiga kecamatan dan seperangkat alat dan bahan untuk analisis kandungan nutrien. Metode yang digunakan yaitu observasi pada 30 responden dengan penentuan lokasi didasarkan pada sentra peternakan sapi perah yang berada di Kab. Malang, sedangkan pemilihan responden menggunakan purposive sampling berdasarkan pada pesternak yang mempunyai minimal dua sapi perah laktasi dan masuk kedalam tiga kategori yaitu peternak skala kecil (2-8 ekor), peternak skala sedang (8-15 ekor) dan peternak skala besar (>15 ekor). Hasil penelitian menunjukkan adanya perbedaan pada jenis bahan pakan konsentratyang digunakan serta status kandungan nutrien diketiga kecamatan tersebut. Hasil terbaik ditunjukkan pada Kecamatan Gondanglegi ditinjau dari jenis bahan pakan konsentrat yang diberikan dan kandungan nutrien pada konsentrat yang diberikan.
\end{abstract}

Kata kunci: Sapi perah, hijauan, konsentrat, kandungan nutrien

How to Cite :

Aprilia, R. M., Hartutik., \& Marjuki. (2018).

Evaluasi Kandungan Nutrien Konsentrat Sapi Perah Rakyat di Kabupaten Malang. Jurnal Nutrisi Ternak Tropis, 1 (1) 54-59
*Corresponding author:

Rizka Muizzu Aprilia

Email : $\underline{\text { didik17101987@gmail.com }}$

Faculty of Animal Science, Brawijaya University, Veteran Street, Malang, East Java, Indonesia. 65145 


\begin{abstract}
The objectives of this research was to evaluate nutrient contents and in vitro feed digestibility of dairy cattle in Malang regency. Samples were collected from 30 dairy cattle farmers in Jabung, Gondanglegi andPujon district. The variable measured consisted of dry matter (DM), organic matter $(O M)$, crude protein $(C P)$, crude fiber $(C F)$, ether extract $(E E)$, nitrogen free extract (NFE) content. The data were analyzed by quantitative descriptive. The result of this research showed that feeds offered on dairy catlle were composed of forages and concentrate. The forages were composed elephant grass, maize stover, native grass, and sugar cane top, while concentrate was composed of concentrate produced by dairy cooperatives of the respective district, tofu waste, cassava waste, cassava roots and cassava peels. Nutrient content of forages and concentrate varied. DM of elephant grass ranged from $16.10 \%$ to $17.41 \%$, OM $84.08 \%$ to $86.05 \%, C P 10.25 \%$ to $14.27 \%$ with DM and OM digestibility $41.67 \%$ to $57.21 \%$ and $45.16 \%$ to $55.90 \%$ respectively. DM of maize stover ranged from $14.83 \%$ to $25.62 \%$, OM $87.39 \%$ to $90.45 \%, C P 10.57 \%$ to $13.84 \%$, with DM and $O M$ digestibility $49.07 \%$ to $63.42 \%$ and $53.15 \%$ to $66.26 \%$ respectively. DM content of concentrate ranged from $87.29 \%$ to $90.42 \%$, OM $89.23 \%$ to $92.44 \%, C P 19.09 \%$ to $21.93 \%$, with DM and OM digestibility $62.27 \%$ to $77.36 \%$ and $65.10 \%$ to $77.23 \%$ respectively. The type of feedstufffor dairy cattle were mostly similar in all districts, but nutrient contents varied.The best result was showed in the Gondanglegi district in terms of the type of feedstuff and its nutrient content.
\end{abstract}

Keywords: Dairy cattle, forage, concentrate, nutrients content

\section{PENDAHULUAN}

Sapi perah adalah salah satu ternak ruminansia yang menghasilkan susu pada periode laktasi. Menurut Mubyarto (1995) Usaha peternakan sapi perah di Indonesia saat ini sebagian besar $(90 \%)$ masih merupakan usaha peternakan rakyat yang merupakan defenisi usaha tani dalam arti sempit dengan tujuan utama untuk memenuhi kebutuhan subsistensi petani dan keluarganya. Hasil produksi susu sapi perah rakyat masih rendah yaitu berkisar antara 10-12 liter/hari, hal ini dapat disebabkan oleh pembibitan, manajemen, danpakan (Elly, Sinaga, Kuntjoro dan Kusnadi, 2008).

Pakan memiliki kontribusi yang paling tinggi yaitu sekitar $60-70 \%$, karena pakan merupakan sumber utama energi bagi ternak .Kebutuhan pakan sapi perah 3\% dari bobot badan, pakan sapi perah umumnya terdiri dari hijauan dan konsentrat. Hijauan pakan sapi perah yang diberikan masih belum memenuhi kebutuhan hidup ternak, sehingga perlu adanya penambahan konsentrat. Pakan konsentrat adalah pakan yang diberikan dengan tujuan untuk meningkatkan jumlah produksi susu sapi perah. Konsentrat berfungsi member tambahan energy dan protein yang diperlukan untuk memenuhi kebutuhan produksi, yang tidak dapat dipenuhi oleh hijauan (Siregar, 2000).

Pakan konsentrat yang digunakan oleh peternak rakyat diproduksi oleh berbagai perusahaan dan KUD di Indonesia. Pakan konsentrat yang digunakan peternak perlu dilakukan pengujian terhadap kualitasnya. Analisis proksimat adalah suatu metoda analisis kimia untuk mengidentifikasi kandungan nutrien seperti protein, karbohidrat, lemak, serat, pada suatu zat makanan dari bahan pakan. Hal ini didukung oleh Hartutik (2012) yang menyatakan bahwa pengukuran kandungan nutrien pakan dapat diketahui melalui analisis proksimat yang dapat menggambarkan secara garis besar tentang kandungan nutrien dalam pakan, yang meliputi kandungan bahan kering, bahan organik/abu, protein kasar, lemak 
kasar, serat kasar, bahan ekstrak tanpa nitrogen dan Total Digestible Nutrien (TDN) pada suatu bahan Analisis proksimat memiliki manfaat sebagai penilaian kualitas pakan terutama pada standar zat pakan yang seharusnya terkandung di dalamnya. Selain itu, analisis proksimat dapat digunakan untuk mengevaluasi dan menyusun formula ransum dengan baik. Mengevaluasi ransum yang telah ada seperti mencari kekurangan pada ransum tersebut kemudian kita bisa menyusun formula ransum baru dengan menambahkan zat makanan yang diperlukan.

Berdasarkan hal tersebut, untuk memaksimalkan pencapaian tingkat produksi sapi perah perlu dilakukan evaluasi pakan konsentrat yang diperdagangkan di Kabupaten Malang dengan tujuan untuk mendapatkan data yang tepat sehingga formulasi pakan yang disusun akan sesuai dengan kebutuhan ternak dan akhirnya akan diperoleh produktifitas yang maksimal.

\section{MATERI DAN METODE}

Penelitian dilaksanakan di ketiga Kecamatan yaitu Pujon, Jabung dan Gondanglegi dengan pemilihan lokasi menggunakan puprosive sampling pada bulan juni hingga November 2018. Data yang dikumpulkan meliputi data primer dari observasi dan wawancara secara langsung pada responden. Metode pengambilan responden dilakukan secara puprosive sampling dengan syarat memiliki minimal 2 sapi perah laktasi dan masuk kedalam tiga kategori yaitu kategori skala kecil (2-8 ekor), skala sedang (9-15 ekor) dan skala besar (>15 ekor). Analisis kandungan nutrien dilakukan di Laboratorium Nutrisi dan Makanan Ternak, Fakultas Peternakan Universitas Brawijaya Malang pada tanggal 9 januari hingga 22 Januari 2018. Materi dalam penelitian adalah seluruh pakan konsentrat yang diberikan peternak pada sapi perah.

\section{Variabel Penelitian}

Variabel yang diukur dalam penelitian ini yaitu kandungan nutrien dari Kecamatan Pujon, Jabung dan Gondanglegi meliputi BK, BO, PK, SK, LK, BETN, TDN .

\section{Analisis data}

Data yang diperoleh dianalisis deskriptif kuantitatif yang berfungsi untuk mendeskripsikan atau memberi gambaran terhadap obyek yang diteliti tanpa membuat kesimpulan yang berlaku pada umum (Sugiono, 2011).

\section{HASIL DAN PEMBAHASAN}

Kandungan nutrien di dalam konsentrat yang diberikan pada sapi perah diharapkan mampu menutupi kekurangan nutrien yang terdapat di dalam hijauan sehingga penting mengetahui kandungan nutrien di dalamnya. Hasil analisis kandungan nutrien konsentrat disajikan pada Tabel 1 .

Tabel 1. Hasil analisis kandungan nutrien konsentrat yang diberikan peternak rakyat di Kecamatan Pujon, Gondanglegi dan Jabung.

\begin{tabular}{|c|c|c|c|c|c|c|c|c|}
\hline Bahan & Kecamatan & BK (\%) & BO $(\%)^{*}$ & PK(\%)* & SK $(\%)^{*}$ & $\mathbf{L K}(\%) *$ & BETN(\%) & $\operatorname{TDN}(\% *)$ \\
\hline \multirow{3}{*}{$\begin{array}{l}\text { Konsentr } \\
\text { at }\end{array}$} & Pujon & $87,56 \pm 1,07$ & $89,23 \pm 1,72$ & $19,09 \pm 1,16$ & $19,10 \pm 1,77$ & $3,37 \pm 0,72$ & $47,68 \pm 2,16$ & $57,33 \pm 4,30$ \\
\hline & Gondanglegi & $89,66 \pm 1,07$ & $92,44 \pm 1,72$ & $21,39 \pm 1,16$ & $20,70 \pm 1,77$ & $4,78 \pm 0,72$ & $45,57 \pm 2,16$ & $63,10 \pm 4,30$ \\
\hline & Jabung & $88,97 \pm 1,07$ & $91,90 \pm 1,72$ & $20,50 \pm 1,16$ & $17,16 \pm 1,77$ & $4,36 \pm 0,72$ & $47,46 \pm 2,16$ & $65,74 \pm 4,30$ \\
\hline
\end{tabular}

Keterangan : (*) Berdasarkan 100\% BK

Hasil analisis Laboratorium Nutrisi dan Makanan Ternak Fakultas Peternakan Universitas Brawijaya Malang. 
Berdasarkan hasil observasi, semua peternak responden memberikan pakan konsentrat untuk memenuhi kebutuhan ternak sapi perah, karena umumnya peternak rakyat memberikan hijauan yang berupa limbah pertanian maupun limbah perkebunan yang kualiatasnya rendah, sehingga peternak memberikan pakan tambahan berupa konsentrat. Hal ini sesuai dengan pernyataan Laryska dan Tri (2013) yang menyatakan bahwa konsentrat memiliki kandungan nutrien yang lebih tinggi dibandingkan dengan hijauan sehingga dapat memberikan peluang kepada ternak agar dapat memaksimalkan pertumbuhan dan produksi susunya. Konsentrat yang diberikan peternak berasal dari Koperasi Unit Desa (KUD) di masing-masing kecamatan, karena umumnya peternak rakyat yang berada di Malang menjadi anggota KUD dimasingmasing kecamatan, sehingga kandungan nutrien dari setiap kecamatan akan berbeda.

Kandungan konsentrat dari ketiga kecamatan yang tertera pada Tabel 1 . Memiliki kandungan nutrien yang berbeda, hal ini dikarenakan bahan baku yang digunakan dalam penyusunan konsentrat dimasing-masing kecamatan berbeda Bahan baku yang digunakan mempunyai nilai nutrisi yang berbeda sehingga konsentrat yang dihasilkan juga memiliki kandungan nutrien yang berbeda. Bahan penyusun konsentrat di Kecamatan Pujon terdiri dari dedak, pollard, kulit kopi tepung jagung, tepung ikan dan tetes, Kecamatan Gondanglegi terdiri dari pollard, onggok, bungkil sawit, bungkil kedelai, dedak padi, bungkil kapuk, kopra dan tepung ikan dan Kecamatan Jabung terdiri dari dedak padi, pollard, tepung jagung, bungkil kelapa, bungkil kedelai, bungkil biji kapuk, bungkil kacang tanah, ampas tahu, garam, mineral mix dan tetes. Kandungan nutrien yang berasal dari ketiga kecamatan tersebut sudah layak untuk di distribusikan/ digunakan oleh peternak karena sudah memenuhi syarat dari Standar Nasional Indonesia yang dimana syarat untuk penggunaan sapi perah laktasi yang memiliki produksi tinggi harus memiliki kandungan kadar air 14\%; BO 90\%; Abu 10\%; PK 15-18\%; LK 7\%; Ca 0,6-1,2\%; P 0,5-0,8\%; NDF 30-35\%; UDP 5,6-7,2\% dan TDN $75 \%$.

Faktor utama penentu pakan memiliki kualitas baik ditentukan oleh kandungan protein yang tinggi. Kandungan protein tertinggi diperoleh dari Kecamatan Gondanglegi dengan kandungan protein kasar yaitu 21,39\% sehingga dapat dijadikan indikator untuk dapat meningkatkan kualitas susu, karena peningkatan kualitas ransum diharapkan dapat meningkatkan kecernaan nutrien dan produksi susu. Broderic (2003) menyatakan bahwa dengan peningkatan kadar protein dalam ransum akan diikuti dengan kecernaan protein kasar yang lebih tinggi, sebagai akibat meningkatnya asupan protein yang dapat dicerna sehingga meningkatnya kecernaan diperkirakan memberikan peluang adanya tambahan asupan nutrien yang dapat digunakan untuk sintesis susu. Protein kasar didalam rumen akan didegradasi oleh mikroba rumen menjadi asam amino dan peptida yang akan dimanfaatkan sebagai protein mikroba dan akan diserap oleh tubuh ternak yang nantinya akan menjadi protein susu, sehingga pemberian konsentrat pada sapi perah harus memperhatikan kandungan nutrien dalam pakan tersebut, hal tersebut diperjelas oleh Rusdiana, Wahyuning dan Sejati (2009) menyatakan bahwa peningkatan jumlah dan mutu konsentrat dapat menjadi salah satu alternatif solusi yang dapat ditempuh peternak untuk meningkatkan kualitas susu.

Kandungan serat kasar dalam pakan sapi perah sangat penting karena serat kasar dalam pakan digunakan sebagai sumber energi bagi ternak. Hasil akhir dari perombakan serat kasar akan menghasilkan volatile fatty acid (VFA) yang berupa asam asetat, asam butirat dan asam propionat. Asam asetat dan butirat merupakan bahan dasar penyusun lemak rantai panjang pada susu, semakin tinggi proporsi hijauan yang diberikan maka kandungan asam asetat dan 
butirat akan semakin tinggi (Suhendra dkk 2016) asam asetat dan butirat akan masuk keperedaran darah menuju hati untuk diubah menjadi asam lemak, selanjutnya masuk kedalam sel-sel sekresi ambing untuk sintesis lemak susu (Mulatmi dkk, 2013), sedangkan pemberian pakan konsentrat yang memiliki serat kasar yang tinggi akan menentukan tingginya kandungan asam propionat. Berdasarkan hasil analisis pada Tabel 1. kandungan serat kasar yang tinggi dihasilka oleh konsentrat yang berasal dari Kecamatan Gondanglegi yaitu $20,70 \%$, sehingga dapat menjadi indikator terhadap tingginya produksi susu, hal ini dijelaskan oleh Ramadhan, Suprayogo dan Sustiyah (2013) yang menyatakan bahwa konsentrat dapat berperan sebagai sumber karbohidrat mudah larut, sumber glukosa untuk bahan baku produksi susu dans ebagai sumber protein yang by pass protein. Konsentrat dapat meningkatkan efisiensi penggunaan energi karena meningkatkan terbentuknya VFA yang utamanya adalah asam propionat. Asam propionat akan amsuk kedala hati kemudian akan diubah menjadi glukosa untuk prekursor laktosa susu.

\section{KESIMPULAN}

Berdasarkan hasil penelitian yang telah diperolah dapat ditarik kesimpulan bahwa kandungan nutrien pada bahan pakan hijauan dan konsentrat yang diberikan peternak rakyat memiliki kandungan nutrien yang berbeda. Kandungan nutrien pakan terbaik diperoleh dari peternak dari Kecamatan Gondanglegi, dengan hasil yang telah tertera pada hasil penelitian diharapkan dapat digunakan sebagai landasan dasar dalam memilih bahan pakan yang akan diberikan pada sapi perah

\section{UCAPAN TERIMA KASIH}

Terima kasih kepada KOP SAE (Pujon), KUD Gondanglegi dan KAN Jabung sebagai penyedia tempat dan materi penelitian, Bapak Sugiono dan Saudari Alik Tisnasari, S.Pt selaku Tim Laboran Laboratorium Nutrisi dan Makanan Ternak Fakultas Peternakan Universitas Brawijaya sebagai mentor dan membantu analisis sampel penelitian.

\section{DAFTAR PUSTAKA}

Broderick, G. A. (2003). Effects of varying dietary protein and energy levels on the production of lactating dairy cows. Journal of Dairy Science, 86(4), 1370-1381. https://doi.org/10.3168/jds.S00220302(03)73721-7

Elly, F. M., Sinaga, B. M., Kuntjoro, S. U., \& Kusnadi, N. (2008). Pengembangan usaha ternak sapi rakyat melalui integrasi sapi tanaman di sulawesi utara. Jurnal Litbang Pertanian, 27, 63-68.

Hartutik. (2012). Metode analisis mutu pakan. Malang: Universitas Brawijaya Press.

Laryska, N., \& Nurhajati, T. (2013). Peningkatan kadar lemak susu sapi perah dengan pemberian pakan konsentrat komersial dibandingkan dengan ampas tahu. Agroveteriner, 1(2), 79-87.

Mubyarto. (1995). Pengantar ekonomi pertanian. Jakarta: LP3ES. 
Mulatmi, S. N. W., Guntoro, B., Widyobroto, B. P., Nurtini, S., \& Pertiwiningrum, A. (2016). Strategi peningkatan adopsi inovasi pada peternakan sapi perah rakyat di daerah istimewa yogyakarta, jawa tengah, dan jawa timur. Buletin Peternakan, 40(3), 219-227. https://doi.org/10.21059/buletinpetern ak.v40i3.12470

Ramadhan, B. G., Suprayogi, T. H., \& Sustiyah, A. (2013). Tampilan produksi susu dan kadar lemak susu kambing peranakan ettawa akibat pemberian pakan dengan imbangan hijauan dan konsentrat yang berbeda. Animal Agriculture Journal, 2(1), 353-361.
Siregar, S. B. (2000). Aspek ekonomis suplementasi pakan konsentrat pada sapi perah Laktasi. Media Peternakan, 23(1), 25-30.

Sugiono. (2011). Statistika untuk penelitian. Bandung: Alfabeta.

Suhendra, D., T. Anggiati, G., Sarah, S., F. Nasrullah, A., Thimoty, A., \& W. C. Utama, D. (2015). Tampilan kualitas susu sapi perah akibat imbangan konsentrat dan hijauan yang berbeda. Jurnal Ilmu-Ilmu Peternakan, 25(1), 42-46.

https://doi.org/10.21776/ub.jiip.2015. 025.01 .06 